\title{
Brachidontes variabilis and Patella sp. as quantitative biological indicators for cadmium, lead and mercury in the Lebanese coastal waters
}

\author{
Khaled F. Nakhlé ${ }^{a^{*}}$, Daniel Cossa ${ }^{b}$, Ghaby Khalaf ${ }^{a}$ and Benoit Beliaeff ${ }^{\mathrm{b}}$ \\ ${ }^{a}$ National Centre for Marine Sciences, National Council for Scientific Research, P.O. Box 534, Batroun, Lebanon \\ ${ }^{\mathrm{b}}$ Institut français de recherche pour l'exploitation durable de la mer (Ifremer), BP 21105, F-44311 Nantes Cedex \\ 03, France \\ *: Corresponding author: Khaled F. Nakhlé
}

\begin{abstract}
The mussel, Brachidontes variabilis, and the limpet, Patella sp., were used as indicators to monitor cadmium, lead and mercury concentrations along the Lebanese coast. Studies were carried out in order to define the best strategy for assessing and minimizing the effects of size and physiological condition on the metal contents of the molluscs, and corrective models were constructed. Metal concentrations in surface water were measured to estimate bioconcentration factors (BCFs). The BCFs varied from $8.3 \times 103$ to $3.4 \times 104$, from $7.5 \times 103$ to $8.0 \times 103$ and from $3.0 \times 104$ to $3.2 \times$ 104 , for $\mathrm{Cd}, \mathrm{Pb}$ and $\mathrm{Hg}$, respectively. For limpets, BCFs varied from $1.7 \times 104$ to $7.4 \times 104$ for $\mathrm{Cd}$, from $2.5 \times 103$ to $6 \times 103$ for $\mathrm{Pb}$ and remained fairly constant at around 104 for $\mathrm{Hg}$. The highest BCFs were associated with lowest contamination levels. The results of the geographical survey exhibited a similar large-scale spatial pattern for the two species and followed the metal concentration distributions measured in the waters.
\end{abstract}

Keywords: Trace metal; Bioindicator; Brachidontes variabilis; Patella sp.; Bioconcentration factors; Mediterranean Sea; Lebanon 


\title{
Brachidontes variabilis and Patella sp. as Quantitative Biological Indicators for Cadmium, Lead and Mercury in the Lebanese Coastal Waters
}

\author{
Khaled F. Nakhlé ${ }^{a, *}$, Daniel Cossa ${ }^{b}$, Ghaby Khalaf ${ }^{a}$ and Benoit Beliaeff ${ }^{b}$ \\ ${ }^{a}$ National Center for Marine Sciences, National Council for Scientific Research, PO Box \\ 534, Batroun, Lebanon \\ ${ }^{b}$ Institut français de recherche pour l'exploitation durable de la mer (Ifremer), BP 21105, \\ F.44311 Nantes cedex 03, France
}

\begin{abstract}
The mussel, Brachidontes variabilis, and the limpet, Patella sp., were selected as quantitative biological indicators to monitor cadmium, lead and mercury concentrations along the Lebanese coasts (Eastern Mediterranean Sea) over a two-year period. Studies were carried out in order to define the best strategy for assessing and minimizing the effects of size and physiological condition on the metal contents of the molluscs, and corrective models were constructed. Metal concentrations in surface water were concurrently measured in order to estimate in situ bioconcentration factors (BCFs). The in situ BCFs for mussels varied from $8.3 \cdot 10^{3}$ to $3.4 \cdot 10^{4}$, from $7.5 \cdot 10^{3}$ to $8.0 \cdot 10^{3}$ and from $3.0 \cdot 10^{4}$ to $3.2 \cdot 10^{4}$, for $\mathrm{Cd}, \mathrm{Pb}$ and $\mathrm{Hg}$ respectively. For limpets, BCFs varied from $1.7 \cdot 10^{4}$ to $7.4 \cdot 10^{4}$ for $\mathrm{Cd}$, from $2.5 \cdot 10^{3}$ to $6 \cdot 10^{3}$ for $\mathrm{Pb}$ and remained fairly constant at around $10^{4}$ for $\mathrm{Hg}$. The highest BCFs were continually associated with the lowest contamination levels. The results of the geographical survey exhibited a similar large-scale spatial pattern for the two species and followed the metal concentration distributions measured in the waters. Low metal levels were found in coastal areas out of the influence of a known metal source. Conversely, the effects of a phosphoric acid plant and a dumpsite were clearly shown on $\mathrm{Cd}$ and $\mathrm{Pb}$ levels. This pilot study allowed the implementation of a sampling strategy in view of a long-term monitoring program along the Lebanese coasts.
\end{abstract}


Keywords: Trace Metal; Bioindicator; Brachidontes variabilis; Patella sp.; Bioconcentration factors; Mediterranean Sea; Lebanon.

\section{Introduction}

Sessile benthic molluscs are used all around the world as quantitative biological indicators for monitoring chemical contaminants in marine environments. This monitoring tool was first proposed by Goldberg in 1975 and launched as the "International Mussel Watch", promoting the use of bivalves as the main sentinel organisms (N.A.S., 1980). During the past three decades, basic research on contaminant metabolism in marine organisms has been conducted and technical developments have been made in order to upgrade the monitoring strategies, and the results have been synthesized in certain review articles (e.g., Phillips, 1980; Bryan et al., 1985; Cossa, 1989; Phillips and Rainbow, 1993). The two main questions which have been addressed related to (i) the search for effective quantitative bioindicators and (ii) the ways of minimizing the effects of physiological parameters, which, in addition to the environmental contamination levels, affect the metal concentrations of the selected bioindicators (Cossa, 1989; Phillips and Rainbow, 1993; Szefer et al., 2002).

Recently, the International Commission for the scientific Exploration of the Mediterranean Sea gathered 24 participants from 14 Mediterranean countries for the foundation of a joint monitoring network along their coasts (CIESM, 2002). The participants agreed to use the Mediterranean mussel, Mytilus galloprovincialis, as the quantitative bioindicator of the contamination by radio-nuclides and trace metals because this species is the most common along the coast of the Mediterranean basin and the Black Sea (e.g., Fisher et al., 1987). However, it was noticed that this species was becoming 
rare and had even disappeared from numerous places in the Levantine Basin. This rareness probably results from the ecosystem changes due to anthropogenic pressure and/or the competition with other species originating from the Red Sea (CIESM, 2002). Transplantation methods (e.g., Fabris et al., 1994) or substitute species are alternative monitoring solutions. The former have recently proved to work effectively along the French Mediterranean coasts (Andral et al., 2004). However, this technique remains very expensive due to manpower, logistic and time requirements (e.g., CIESM, 2002). In the present work that aims to monitor the metal contamination along the Lebanese coasts, we chose to explore a less expensive method by selecting the most appropriate wild molluscs existing along the coasts we want to monitor. During its recent workshop, CIESM (2002) recommended the African mussels of the genus Perna or Brachidontes variabilis which both belong to the Mytilidae family, as being the best substitute species for Mytilus sp. As a result of an organism inventory along Lebanese coasts, the Perna sp. was not found in abundant numbers and we concluded that the Patella sp. was the most suitable organism because it is abundant and widespread. In addition, for purposes of comparison with other Mediterranean regions, we also selected the bivalve Brachidontes variabilis, which is also present in several places along the Lebanese coasts.

It is now a well-established fact that the metal content in mollusc is a function of inherent (biological) and external (including the contaminant bioavailability in the environment) factors, which combine to produce a quasi steady state between the metal concentration within the organism and its surrounding environment. For contamination monitoring purposes, it is important to maximize the significance of external factors by minimizing the biological ones. The main biological processes involved in metal 
retention in soft tissues of molluscs are growth and reproduction (e.g., Fisher, 1984; Cossa, 1989; Phillips and Rainbow, 1993). In fact, the growth rate and reproduction cycling may change the metal concentration of the organisms by diluting or concentrating the metal content of the organisms. Under certain circumstances, this may give rise to spurious conclusions in monitoring surveys, and the minimization of such effects is thus of considerable importance in order to assess the contamination level and describe the spatial distribution. Boyden $(1974,1975)$ and Cossa $(1979,1980,1985)$ showed that size (length, weight or age) of biomonitors and season (reproduction and storage) of collection are the main factors affecting their accumulated concentrations of trace metals. It has been demonstrated that a sampling frequency of four times per annum is suitable for describing the main features of the seasonal variation for metals within Mytilus sp. at mid-latitudes (e.g., Claisse, 1990). Boyden (1974, 1977) stressed that for studying the size effect, it is important to have a size range that is as broad as possible and includes young animals with the highest metabolic turnovers, as well as adults and senescent individuals with a quasi-stopped growth. This approach makes it possible to provide an accurate definition of the type of relationship existing between metal concentration and size.

The present work describes the geographical patterns of $\mathrm{Cd}, \mathrm{Pb}$ and $\mathrm{Hg}$ distributions in the Lebanese coastal waters using Brachidontes variabilis and Patella sp. as quantitative bioindicators. It includes the investigation of size and seasonal effects on metal content of the two biomonitors, which allows the construction of models for the correction of size and physiological condition effects. The distribution patterns are 
compared to metal measurements in waters and bioconcentration factors are infered; they are also discussed in term of background concentrations and contamination sources.

\section{Materials and methods}

\subsection{Choice of bioindicators for the Lebanese coasts}

Several species presented themselves as likely candidates. In fact, pilot studies had already been performed along the Eastern Mediterranean coasts, i.e., in Egypt, Mytilus minimus, Donax trunculus and Mactra corallina have been used to monitor divalent metals (Aboul-Dahab, 1985; Abdel Moati and Atta, 1991; El-Rayis and al.,1997; Khalid, 1997; Ahdy, 1999) and in Israel, two species of bivalves (Mactra corallina and Donax sp.) and two gastropods (Patella sp. and Cellana rota) have been used to monitor trace element contamination (Herut et al., 1999). In addition, in Syria, Patella sp. and Monodonta turbinata have been successfully used for Cr, Cd and Co (Al-Masri, 2002) and in Turkey, the commonly used species have been Perna perna and Mytilus galloprovincialis (Tuncer and Uysal, 1982). Early studies of trace metal contamination along the Lebanese coast did not follow a common methodology, especially with regard to the use of known and established bioindicators. Shiber (1977 and 1981) and Shiber and Shatila (1978) explored different molluscs and crustacean species in order to monitor trace elements along the coastline of Beirut (Eriphia verrucosa, Pachygrapus transverses, Patella sp., Brachidontes variabilis, Monodonta turbinata). Other studies used limpets and shrimps as bioindicators of the contamination of the Lebanese coast (Kayal, 1981). Since the end of the Lebanese war in 1991, no new information has been available in the open literature, whereas the state of the environment has drastically changed due to the extensive urbanization of the coastal area. In the present work, two 
species were selected as potential quantitative bioindicators: Brachidontes variabilis and Patella $s p$. The first species, also known as Mytilus arabicus, is a typical inhabitant of hard substrata and lives in shallow water (at sea level or just below) attached mostly in clusters to rocks and stones by its byssus. Its abundance seems to be negatively associated with wave exposure. In addition, the animals densely colonize debris. They entangle the hard fragments by byssus threads into larger and heavier masses. In this way they may reach very high densities and completely cover a rocky shore to form a "mytilid bed". This mussel has an elongated shell (between 20 and $30 \mathrm{~mm}$ ) with a purplish brown outside. The inside of the valves is purple and becomes whitish in the ventral region. Edges are carved and present a hinge with dysodont teeth (Le-Loeuff and Zabi, 1994). It is a Lessepsian species, which means that it has invaded the Mediterranean coast since the opening of the Suez Canal.

Patella sp. inhabits the medio-littoral zone where it forms dense populations. The limpet is suited to this ecosystem through its organization enhancing, its resistance to the battering of the waves and to dehydration, given its developed pedal muscle. Furthermore, it can live for more than 10 years. When it lives on calcareous rocks it digs a depression to be better shielded from dehydration during periods of dryness. During high tides, the limpet leaves its shelter and grazes on macroscopic algae, different debris or microscopic algae (diatoms) covering the surrounding rock surface. During low tides, it returns back to its shelter and inhabits exactly the same place. Its shell perfectly fits to the rock, preventing losses of water by evaporation at low tide.

In this paper Brachidontes variabilis and Patella sp. will be respectively referred to mussel and limpet. 


\subsection{Animal sampling}

Different sampling techniques were used depending on the purpose and on the molluscs.

To study the effect of animal size on metal content, forty specimens of each species were collected on the same rock at Station SR (Fig. 1). This station was selected for the size effect study because of the abundance of the molluscs and the cohabitation of limpets and mussels in a narrow area $\left(25 \mathrm{~m}^{2}\right)$ where environmental conditions are homogeneous. The size of the collected animals ranged from 8 to $26 \mathrm{~mm}$ for the mussels and from 7 to $41 \mathrm{~mm}$ for the limpets. The water temperature and salinity were $21.0^{\circ} \mathrm{C}$ and $39 \%$ respectively during the sampling period (May 2003).

In order to study spatial trends, the nine selected sampling sites included almost pristine stations for reference and stations under the influence of potential sources of chemical contaminants. The stations stretch along $50 \mathrm{~km}$ of the Lebanese coast between the capital city of Beirut in the South and the coastal village of Selaata in the North (Fig. 1). This area hosts a large part of the industrial and residential activities in the Lebanon, which are summarized on Table 1.

Two sets of 10 specimens of each species were collected at each of the 9 stations indicated in Fig. 1. One set was used for $\mathrm{Cd}$ and $\mathrm{Pb}$ analyses, the other for $\mathrm{Hg}$. In order to minimize the effect that size (age) exerts on the metal concentrations, specimens were selected with a standard size, $18-23 \mathrm{~mm}$ long for Brachidontes variabilis and $25-30 \mathrm{~mm}$ long for Patella sp. Immediately after collection, shells and soft tissues were cleaned with a nylon brush in order to eliminate sediment and other impurities and then rinsed with seawater. The soft parts, including interstitial fluid, were removed from their shells and 
individually transferred into $50 \mathrm{~mL}$ polypropylene (PP) tubes for $\mathrm{Cd}$ and $\mathrm{Pb}$ analyses and, in $2 \mathrm{~mL}$ PP tubes for the $\mathrm{Hg}$ determinations. The mussels were collected only at five stations (SR, S, B, K and H, Fig. 1) because of the scarcity of these individuals at the other stations.

The nine stations were sampled within one day and on eight occasions in February, May, August and November 2002 and 2003. This sampling strategy made it possible to follow the seasonal variations of the trace metal concentrations in the soft tissues of the molluscs. Temperature and salinity were registered during the collections.

\subsection{Sample pretreatment}

Back in the laboratory, the animal shells were sized and weighed. The length of the brachidontes was measured as the longest distance from the umbo. In the case of the limpets, the length was chosen as the longest diameter of the ellipse. A condition index (CI), a proxy for physiological condition of the mollusc, was calculated for each individual as the ratio between the dry weight of the soft tissue divided by the shell weight.

\subsection{Analyses}

For cadmium and lead analysis, samples were dried in a stainless steel incubator at $60^{\circ} \mathrm{C}$ for three days in the PP tubes. The entire soft tissues of each animal $(20-400 \mathrm{mg}$, dry weight) were then digested in concentrated nitric acid at $90^{\circ} \mathrm{C}$ for 3 hours. The mineralized aqueous solutions were analyzed by atomic absorption spectrometry using a graphite furnace and Zeeman correction (Varian Spectr-AA800) in accordance with the protocol described by Chiffoleau et al. (2003). For mercury analysis, samples were 
freeze-dried and the analyses were performed directly on dry tissue without mineralization (Advanced Mercury Analyser AMA254 ${ }^{\circledR}$, Altech) (Cossa et al., 2002). For the study of the size effect, $\mathrm{Hg}$ was measured on the same digesta as that used for $\mathrm{Cd}$ and $\mathrm{Pb}$ given the excessively small amount of material available for the analyses. In this case $\mathrm{Hg}$ determinations were performed after $\mathrm{SnCl}_{2}$ reduction by cold vapor atomic fluorescence spectrometry (CVAFS) in accordance with Sanjuan and Cossa (1993). Metal concentrations were expressed on the basis of the dry weight of the soft tissues (dw).

The detection limits of the analyses were $0.02,0.2$ and $0.007 \mathrm{ng} \cdot \mathrm{mg}^{-1}(\mathrm{dw})$ for $\mathrm{Cd}$, $\mathrm{Pb}$ and $\mathrm{Hg}$ respectively and their reproducibility varied between 3 and $10 \%$. Accuracies of the determinations were estimated on a daily basis using certified reference material (CRM): CRM 278r and SRM 1566b from the Bureau Communautaire de Référence (EU) and the National Institute of Standards and Technology (USA); the analytical results obtained were between the certified analytical limits.

Metal concentrations in surface seawater used for the calculation of in situ bioconcentration factors (BCFs) concerned the very near-shore zone (within $400 \mathrm{~m}$ from the shoreline). Water samples were obtained using ultra-clean the procedures for sampling and analyses (including class 100 clean laboratory facilities). In brief, surface water samples have been handily (wearing non powdered PE gloves) collected from a rubber boat or by divers into acid cleaned Teflon (FEP) bottles for Hg and in low density polyethylene (LDEP) bottles for $\mathrm{Cd}$ and $\mathrm{Pb}$. Back to the laboratory in Bartoun, the samples were acidified with hydrochloric for $\mathrm{Hg}$ and with nitric acid for $\mathrm{Cd}$ and $\mathrm{Pb}$ (Suprapur acids from Merck). The metal determinations have been performed in Nantes, 
within 4 months after sampling. The gold-amalgamation-cold-vapor technique (EPA 1631) was used for the $\mathrm{Hg}$ determination in water, while a complexation/extraction method was used for $\mathrm{Cd}$ and $\mathrm{Pb}$. Atomic fluorescence and atomic absorption detections have been used for $\mathrm{Hg}$, and $\mathrm{Cd}$ and $\mathrm{Pb}$ respectively. The detailed analytical procedures are given elsewhere (Cossa et al., 2003; Chiffoleau et al., 2002). The analytical performances for $\mathrm{Cd}$ and $\mathrm{Pb}$ were checked using a $\mathrm{CRM}$ (CASS-3 seawater sample from the National Research Council of Canada). Our results were always found within the certified analytical limits. No CRM was available for the $\mathrm{Hg}$ determination in seawater; thus, the accuracy for this element was checked on the occasion of intercomparison exercises (e.g., Quemerais and Cossa, 1995)

\subsection{Statistical tests}

Given that the frequency distributions of the metal concentrations in the molluscs were log-normal, the statistical tests were performed on log transformed data. Analyses of variance (ANOVA) were carried out using the software "S-PLUS" in order to compare mean concentrations in relation to time (season, year), location and condition index.

\section{Results and Discussion}

The results are presented here in four sections, according to the main factors affecting the metal concentration in the selected molluscs. Firstly, the relationships between metal concentration and the size of the molluscs are described. Secondly, the effects of time (season, year), physiology condition (CI) and station are assessed, on a size selected animal range, using an analysis of variance. After minimizing the CI effect, the geographical trends are discussed and the BCFs calculated. Finally, the contamination 
levels measured in this study are compared to similar monitoring from other coastal areas.

\subsection{Metal concentrations versus size}

Metal concentrations in the soft tissues were plotted against the longitudinal shell length for both mussels and limpets; results are illustrated in figures 2 and 3 respectively.

Concentrations of $\mathrm{Cd}$ and $\mathrm{Pb}$ in mussel soft tissues generally decreased significantly with increasing size with $\mathrm{R}^{2}$ values of 0.43 and 0.46 , respectively (Fig. 2). As a rule, individual $\mathrm{Cd}$ concentrations varied within a factor of 5 for an increase in shell length from 8 to $26 \mathrm{~mm}$. For $\mathrm{Pb}$ the factor was 7 for the same length variation. Mercury concentrations did not display any trend with the size of the bivalves within the chosen range (Fig. 2). Exceptional high concentrations could be observed for certain individuals

up to $7.9,3.6$ and $0.84 \mathrm{ng} \cdot \mathrm{mg}^{-1}(\mathrm{dw}$ ) for $\mathrm{Cd}, \mathrm{Pb}$ and $\mathrm{Hg}$. Such individuals have already been described (Boyden, 1974, 1977) and were qualified as "super-accumulators".

As for limpets, we observed results similar to those for the mussel for $\mathrm{Pb}$ and $\mathrm{Hg}$ concentrations (Fig. 3): $\mathrm{Pb}$ concentrations decreased with size increase, whereas $\mathrm{Hg}$ concentrations were unrelated to size. In addition, certain unusually high concentrations were also observed of up to 2.4 and $1.0 \mathrm{ng} \cdot \mathrm{mg}^{-1}$ ( $\mathrm{dw}$ ) for $\mathrm{Pb}$ and $\mathrm{Hg}$. The situation was radically different for $\mathrm{Cd}$, for which we observed a general increase in concentrations with increasing shell length (Fig. 3).

These types of variation have already been found for molluscs (e.g., Bayne, 1976; Boyden, 1977). These authors deduced that metal-size relationships are species-specific and express the differences in the metal turnovers and the metabolism activity changes 
during the lives of the animals. In addition, other authors have shown that the parameters of the relationship could vary with season and metal exposure levels (Cossa et al., 1980, Cossa and Rondeau, 1985). Present results for $\mathrm{Cd}$ and $\mathrm{Pb}$ are consistent with these previous interpretations. Metal concentrations in the soft tissue of B. variabilis decrease with increasing size as the result of (i) the dilution of the metal load by the growth of soft tissues and (ii) the slowing down of the metabolism with the increasing age of the animal. The net accumulation of $\mathrm{Cd}$ in limpets with age is also a well-established fact (e.g., Boyden, 1974; 1977). Certain specific physiological behavior of the limpets may account for the high Cd accumulation rate. Cubadda et al. (2001) and Davies and Cliff (1999) suggested that the feeding habits are involved in the process. Qiu et al. (2001) demonstrated using kinetic modeling that the uptake from dietary phase (especially bacteria) dominated metal accumulation in the slipper limpets $(87 \%$ for $\mathrm{Cd})$.

For Hg in bivalves results from Cossa and Rondeau (1985) also showed a near zero slope for the metal $v s$ shell length relationship. It has been suggested that the absence of relationships between $\mathrm{Hg}$ concentration and the mollusc size is the result of the opposite accumulation rates of inorganic and methylmercury (Mikac et al., 1999). While the inorganic mercury concentrations are decreasing with age, the methylmercury concentrations are increasing. The net result is a near zero slope for the relationship between size (age) and the total mercury concentration of the mollusc, which does not allow to sort out the opposite bioconcentration properties of the various chemical species. This hypothesis is consistent with the present results, but remains to be confirmed.

For monitoring purposes, it can be concluded that the choice of a very narrow size shell range that we have chosen in this study $(<5 \mathrm{~mm})$ has minimized the effect of the 
size on the metal concentrations of the candidate bioindicators. In addition, the average size selected in this study (around 15 and $25 \mathrm{~mm}$ for the mussel and the limpets respectively) are within the most stable variation ranges in metal concentration, avoiding the smallest and the largest individuals, these extrema including most of the super accumulators. This strategy allows a more precise comparison of metal concentration means among stations.

\subsection{Physiological and geographical influences}

Results of ANOVA to test the effects of season, years, CI and stations are given in Table 2 for the mussels and in Table 3 for the limpets. For the three metals, the residues were relatively small indicating that the chosen factors explained most of the variability and thus were relevant explanatory factors. The highly significant $\mathrm{F}$ values for the station and $\mathrm{CI}$ indicated the main influence of these two factors.

For B. variabilis, $\mathrm{Cd}, \mathrm{Pb}$ and $\mathrm{Hg}$ concentrations depend very highly on the relevant station along the Lebanese coast and on the physiological state of the animal. This shows the capacity of this mussel as a quantitative bioindicator of geographic variations of the contamination by $\mathrm{Cd}, \mathrm{Pb}$ and $\mathrm{Hg}$, and shows the need to consider $\mathrm{CI}$ in order to optimize the information obtained from the mussel on the bioavailability of the three metals. In addition, the tested interactions among station, year and CI were significant only for $\mathrm{Hg}$, for which the effect of the station over the two years was not identical. For limpets, the ANOVA showed small residues, and highly significant values of F for the station and CI. Metal concentrations of Patella sp. along the Lebanese coast were very dependent on both the geographical origin and the physiological state of the animals. It can be inferred that limpets are also relevant indicators of the geographic 
variations of metal contamination of the environment. The station-year interaction is significant for all three metals, which could be attributed to the fact that only five stations were used for mussels as opposed to nine for limpets.

\subsection{Spatial trends}

The Cd concentration means in the soft tissue of the mussel ranged from $1.08 \pm$ $0.25 \mathrm{ng} \cdot \mathrm{mg}^{-1},(\mathrm{dw})$ at Station H to $4.00 \pm 0.67 \mathrm{ng} \cdot \mathrm{mg}^{-1}$ (dw) at Station SR (Fig. 4). Low $\mathrm{Cd}$ concentrations measured in the water at Station $\mathrm{H}$, averaging $6 \mathrm{ng} \cdot \mathrm{L}^{-1}$ (Table 2), suggests that $\mathrm{Cd}$ concentrations measured in the soft tissues of $B$. variabilis do reflect the background level of an uncontaminated site along the Lebanese coasts. Conversely, $\mathrm{Cd}$ concentrations in mussels from Stations SR and S $\left(2.99 \pm 0.17 \mathrm{ng} \cdot \mathrm{mg}^{-1}, \mathrm{dw}\right)$, which are close to the source of phosphogypsum (the factory at Selaata), were very high (Fig. 4). Consistently, Cd concentrations in the surface water at Station SR ranged from 21 to 156 $\mathrm{ng} \cdot \mathrm{L}^{-1}$ according to the seasons (Nakhlé, 2003). Cd concentrations tended to decrease in mussel tissue from SR southwards as the influence of the Selaata plant decreases (Fig. 4) and the same pattern was observed for Cd in surface sea water (Nakhlé, 2003). The lead concentration means in the mussels ranged from $1.0 \pm 0.2 \mathrm{ng} \cdot \mathrm{mg}^{-1}(\mathrm{dw})$ at Station $\mathrm{H}$ to $2.5 \pm 0.7 \mathrm{ng} \cdot \mathrm{mg}^{-1}(\mathrm{dw})$ at Station S (Fig. 4), where Pb concentrations in the surface water ranged from 19 - 48 to $67-180 \mathrm{ng} \cdot \mathrm{L}^{-1}$ (Table 2). Hg concentrations in soft tissues of $B$. variabilis were uniformly low at Stations $\mathrm{S}, \mathrm{B}, \mathrm{K}$ and $\mathrm{H}$, with means lower than $0.2 \pm 0.1$ $\mathrm{ng} \cdot \mathrm{mg}^{-1}(\mathrm{dw}) . \mathrm{T}$ the highest concentrations were observed at station SR $\left(0.6 \pm 0.1 \mathrm{ng} \cdot \mathrm{mg}^{-}\right.$ ${ }^{1}$, dw) (Fig. 4), where high levels of $\mathrm{Hg}$ were also measured in surface coastal water in summer (SR: $0.65 \mathrm{ng} \cdot \mathrm{L}^{-1}$ compared to $0.34 \mathrm{ng} \cdot \mathrm{L}^{-1}$ at Station $\mathrm{H}$, according to Nakhlé, 2003). 
Cd concentration means in limpets were very high at Stations SR and S (Fig. 5): $7.7 \pm 2.1 \mathrm{ng} \cdot \mathrm{mg}^{-1}(\mathrm{dw})$ and $8.7 \pm 3.8 \mathrm{ng} \cdot \mathrm{mg}^{-1}(\mathrm{dw})$. The lowest concentrations were found at Stations $\mathrm{Z}$ and A with means of $0.8 \pm 0.4 \mathrm{ng} \cdot \mathrm{mg}^{-1}(\mathrm{dw})$ and $\left(0.6 \pm 0.2 \mathrm{ng} \cdot \mathrm{mg}^{-1}(\mathrm{dw})\right.$ respectively. Even at Station B situated at $4 \mathrm{~km}$ south of the plant, Cd contamination can be measured with a mean of $5.4 \pm 2.3 \mathrm{ng} \cdot \mathrm{mg}^{-1}(\mathrm{dw})$. Concentrations decreased to $2.5 \pm$ $1.2 \mathrm{ng} \cdot \mathrm{mg}^{-1}(\mathrm{dw})$ and $2.4 \pm 0.7 \mathrm{ng} \cdot \mathrm{mg}^{-1}(\mathrm{dw})$ at Stations $\mathrm{K}$ and $\mathrm{H}$. Pb concentration means are illustrated in Figure 5. The highest concentrations were measured in Stations A and J $\left(1.8 \pm 0.9 \mathrm{ng} \cdot \mathrm{mg}^{-1}(\mathrm{dw})\right.$ and $2.6 \pm 1.7 \mathrm{ng} \cdot \mathrm{mg}^{-1}(\mathrm{dw})$. These stations correspond to the large cities (Station Jat the Bay of Jounieh and Station A in a north suburb of Beirut). To date, these cities have been deprived of wastewater treatment plants and are subject to intense car traffic, some of which still uses leaded gasoline. In addition, Station A is under the influence of the Anthelias River and the effluents of the dump site of Dora, which have both been shown to be contaminated by $\mathrm{Pb}$ (Nakhlé, 2003). The lowest concentration means $\left(0.5 \pm 0.1 \mathrm{ng} \cdot \mathrm{mg}^{-1}, \mathrm{dw}\right)$ were estimated in Station SR, far from the urban activities. Concentrations of $\mathrm{Hg}$ in limpets were very low at all stations with a maximum at Station SR $\left(0.2 \pm 0.1 \mathrm{ng} \cdot \mathrm{mg}^{-1}, \mathrm{dw}\right)$ and a minimum at Station $\mathrm{K}\left(0.14 \pm 0.01 \mathrm{ng} \cdot \mathrm{mg}^{-1}, \mathrm{dw}\right)$ (Fig. $5)$.

In summary, similar geographical patterns were observed for the two species and the three metals. In particular $\mathrm{Cd}$ contamination of the Selaata plant was clearly demonstrated by both bioindicators. However, limpets accumulate $\mathrm{Cd}$ more efficiently than mussels. In addition, the geographical patterns of $\mathrm{Cd}$ and $\mathrm{Hg}$ concentrations in the mussels and in the near-shore surface waters are roughly parallel (Figure 6). However, 
this does not imply that linear models exist between the metal content in water and biota, the relationships are more complex (see section 3.5 on the $\mathrm{BCFs}$ ).

\subsection{Effect of CI on spatial trends}

The ANOVAs clearly showed that the variations of the physiological condition of the molluscs (mainly the storage and gonadic tissue variations during the seasons), expressed by the CI also affected metal concentrations in the mussel (Tables 3 and 4). In the case of the mussels, in order to standardize the CI effect, we used the linear relation between $\mathrm{CI}$ and metal concentrations (Table 5) to obtain a corrected metal concentration for a fixed theoretical CI. The corrected values appear in Table 6. As expected, these results do not contradict the interpretations above nor prompt further hypotheses. In the case of the limpets, we observed that the lowest $\mathrm{Cd}$ concentration values at Stations $\mathrm{Z}$ and A correspond to the individuals with the highest CI, resulting from a dilution of the contents in metals of the animals. However, no statistically significant differences were found when plotting the 3 metal concentrations $v s$ the CI. Thus, CIs for limpets do not generate systematic bias and therefore neither change the geographic pattern in the previous section nor its interpretation.

\subsection{In situ bioconcentration factors}

Metal concentrations were measured in surface waters within the first kilometer from the shoreline. On the other hand, detailed results of the summer and winter sampling campaigns were described elsewhere (Nakhlé, 2003). For the very nearshore waters, surrounding the molluscs sampling stations $(<50 \mathrm{~m}$ from the shore) metal concentrations in unfiltered seawater ranged from 6 to 156,19 and 320 and 0.3 to $7.9 \mathrm{ng} \cdot \mathrm{L}^{-1}$ for $\mathrm{Cd}, \mathrm{Pb}$ and $\mathrm{Hg}$ respectively. These measurements and metal concentrations in mollusc allowed 
the calculation of in situ bioconcentration factors (BCFs). The BCFs are defined as the ratios of the metal concentrations in the molluscs, expressed in $\mathrm{kg}$ of wet weight (ww) soft tissue, to the metal concentrations, expressed by $\mathrm{kg}$ of seawater. The BCFs for cadmium in mussels ranged from $3.4 \cdot 10^{4}$ at a non-contaminated zone to $8.3 \cdot 10^{3}$ at a contaminated one; $\mathrm{BCF}$ for $\mathrm{Pb}$ ranged from $8 \cdot 10^{3}$ at the non-contaminated site to $7.5 \cdot 10^{3}$ at the contaminated one and for $\mathrm{Hg}$ from $3 \cdot 10^{4}$ to $3.2 \cdot 10^{4}$. The calculated $\mathrm{BCF}$ for cadmium in limpets ranged from $7.4 \cdot 10^{4}$ at a non-contaminated site to $1.7 \cdot 10^{4}$ at a contaminated one and $\mathrm{BCFs}$ for $\mathrm{Pb}$ ranged from $6 \cdot 10^{3}$ at a non-contaminated site to 2.5 $\cdot 10^{3}$ at a contaminated one and remained constant for $\mathrm{Hg}$ at $10^{4}$. These in situ $\mathrm{BCFs}$ tend to be higher than factors obtained from laboratory experiments (e.g., Fowler, 1982; Gagnon and Fisher, 1997). BCFs calculated from data from natural environments include the both uptake routes, water and food. It is thus rational that the values were higher than those obtain in short-term laboratory conditions, where the metal spikes were performed only in the water phase. In addition, the findings of smaller BCFs in contaminated environments support the conclusion by McGeer et al. (2003), which pointed out from a large literature review that $\mathrm{BCF}$ values are inversely correlated with exposure concentrations. The origin of the phenomenon should be search in the homeostasis function for certain elements, and those with similar chemical properties, and more generally in the animal's metabolisms for each metal.

\subsection{Worldwide comparisons with metal concentrations in other mussels and limpets}

Two main databases on metal concentrations in mussel can be used for comparison, i.e., the French "Réseau National d'Observation" (RNO, 
www.ifremer.fr/envlit) and "Mussel Watch" in the USA (www8.nos.noaa.gov/cit/nsandt/download/mw_monitoring.aspx).

\subsubsection{Mussels}

For $\mathrm{Cd}$, the low concentration found at Station $\mathrm{H}\left(1.1 \mathrm{ng} \cdot \mathrm{mg}^{-1}, \mathrm{dw}\right)$ is similar to the average of the concentrations in mussels from the French coasts $\left(1.0 \mathrm{ng} \cdot \mathrm{mg}^{-1}, \mathrm{dw}\right)$, and lower than that of the US coasts $\left(1.6 \mathrm{ng} \cdot \mathrm{mg}^{-1}\right.$, dw) (RNO, 1996) (Table 7). The maximum of $4.0 \mathrm{ng} \cdot \mathrm{mg}^{-1}$, (dw) observed near the Selaata plant, despite its reflecting the presence of a hot-spot, is far lower than the maximum attained in France and the USA (13 and $13.5 \mathrm{ng} \cdot \mathrm{mg}^{-1} \mathrm{dw}$, respectively). The $\mathrm{Pb}$ concentrations from our study are in the low range of values found along French and USA coasts, averaging 2.7 and $1.9 \mathrm{ng} \cdot \mathrm{mg}^{-1}$ (dw) with maximal concentrations up to 30 and $21 \mathrm{ng} \cdot \mathrm{mg}^{-1}$ (dw) (RNO, 1996) (Table 7). For $\mathrm{Hg}$ concentrations levels in mussels are similar for the Lebanese, French and US coasts (Table 7).

\subsubsection{Limpets}

The Cd values at Stations SR and S are comparable to concentrations found at in contaminated sites in Italy, averaging $8.8 \mathrm{ng} \mathrm{mg}^{-1}$ (Cubadda et al., 2001), while the levels found in Stations $\mathrm{H}$ and $\mathrm{J}$ (respectively $2.4 \mathrm{ng} \cdot \mathrm{mg}^{-1}$ and $2.5 \mathrm{ng} \cdot \mathrm{mg}^{-1}$ ) are comparable to those measured in limpets of the same size $\left(2.5 \mathrm{ng} \cdot \mathrm{mg}^{-1}\right.$ for limpets of $\left.34 \mathrm{~mm}\right)$ (Ramelow, 1985) at the non contaminated sites along the Turkish coasts. These values are lower than those observed at stations considered in Italy as non contaminated with levels ranging from 3.5 to $4.8 \mathrm{ng} \cdot \mathrm{mg}^{-1}$ (Cubadda et al., 2001). None of the consulted references displays Cd concentrations in limpets as low as those measured at Stations $\mathrm{Z}\left(0.80 \mathrm{ng} \cdot \mathrm{mg}^{-1}\right)$ and A 
$\left(0.57 \mathrm{ng} \cdot \mathrm{mg}^{-1}\right)$. As a result, naturally contaminated levels would range from values as low as $0.57 \mathrm{ng} \cdot \mathrm{mg}^{-1}$ to 2 or even $3 \mathrm{ng} \mathrm{mg}^{-1}$.

The $\mathrm{Pb}$ yearly means recorded at Stations $\mathrm{J}$ and A (respectively 2.6 and 1.8 $\left.\mathrm{ng} \cdot \mathrm{mg}^{-1}\right)$ were higher than those found in a contaminated harbour in Italy $\left(1.4 \mathrm{ng} \cdot \mathrm{mg}^{-1}\right)$ (Cubadda et al., 2001), but close to those registered in certain polluted sites in Turkey $\left(2.5 \mathrm{ng} \cdot \mathrm{mg}^{-1}\right)$ (Ramelow, 1985). The lowest values were close to $1 \mathrm{ng} \cdot \mathrm{mg}^{-1}$ but remained higher than those found in Turkey (from 0.2 to $0.6 \mathrm{ng} \cdot \mathrm{mg}^{-1}$ ) and in Italy (from 0.1 to 0.3 $\left.\mathrm{ng} \cdot \mathrm{mg}^{-1}\right)$. This difference can be explained by the intensive anthropogenic activity in the relevant region linked to heavy car traffic.

Mercury levels in limpets are difficult to compare due to a paucity of information and studies in most regions of the Mediterranean basin. However a unique study in the northern Tyrrhenian Sea has shown that levels of mercury in limpets ranged from 0.29 to $1.2 \mathrm{ng} \cdot \mathrm{mg}^{-1}$ (Bargagli et al., 1985). The authors explain high concentrations by higher background levels of the northern Tyrrhenian Sea. In the present study, mercury levels ranged from 0.04 to $0.23 \mathrm{ng} \cdot \mathrm{mg}^{-1}(\mathrm{dw})$ observed at stations $\mathrm{K}$ and SR.

\section{Conclusions}

The present research demonstrated the ability of two local molluscs, a mussel (Brachidontes variabilis) and a limpet (Patella sp.), to monitor $\mathrm{Cd}, \mathrm{Pb}$ and $\mathrm{Hg}$ contamination along the Lebanese coasts (Eastern Mediterranean Sea). The findings have made it possible to quantify the effects of the size and the physiological condition of the animals on the metal concentration of their soft tissues and provided the methodological basis for the implementation of a permanent monitoring programme. Once a size range had been selected, the effect of the physiological state of the mollusc, represented by the 
condition index (IC), could be minimized by normalization using simple regression metal specific models. By getting rid of such influences, very significant geographical trends could thus be shown in the distribution of metal concentrations in the animals and safely interpreted as the result of the contamination of the surrounding environments. Both molluscs provided the same spatial patterns, which, in the present two-year monitoring exercise, could be related to the main local and identified contamination sources, namely a phosphoric acid plant for $\mathrm{Cd}$ and urban discharges for $\mathrm{Pb}$. In addition, there was a convergence in the comparison between the dissolved $\mathrm{Cd}$ concentrations in surface water and the concentrations measured in mussel tissue.

\section{Acknowledgments}

This work was supported by the National Council for Scientific Research in Lebanon (CNRSL) and the French Research Institute for the sustainable Exploitation of the

Sea (IFremer). The authors wish to thank D. Auger, E. Chartier, E. Tarek and J. Bretaudeau for their help at sea and in the laboratory. This manuscript has been improved by the helpful comments of an anonymous referee.

\section{References}

Aboul-Dahab, O. 1999. Chemical cycle of inorganic pollutants in the ecosystem west of Alexandria between Anfoushy and Agamy. PhD thesis, Alexandria University, Egypt. 
Ahdy, H.H. 1999. Dynamics of $\mathrm{Cd}$ and $\mathrm{Pb}$ in Abu Kir Bay and their effect on marine organisms. $\mathrm{PhD}$ thesis, Alexandria University, Egypt.

Al-Masri, M.H. 2002. Marine environment studies on the Syrian coast: biomonitors. CIESM Workshops Series, 15, $136 \mathrm{pp}$.

Andral, B., Stanisiere, J.Y., Sauzade, D., Damier, E., Thebault, H., Galgani, F., Boissery, P. 2004. Monitoring chemical contamination levels in the Mediterranean based on the use of mussel caging. Marine Pollution Bulletin, 49, 704-712.

Bargagli, R., Baldi, F., Leonzio, C. 1985. Trace metal assessment in sediment, molluscs and reed leaves in the Bay of Follonica (Italy). Marine Environmental Research, 16, 281-300.

Bayne, B. 1976. Marine mussels: their ecology and physiology. Cambridge University Press, 506 pp.

Boyden, C.R. 1974. Trace elements content and body size in molluscs. Nature, 251, 311314.

Boyden, C.R. 1977. Effect of size upon metal content of shellfish. Journal of Marine Biological Association of U.K., 57, 675-714.

Chiffoleau, J-F., Auger, D., Chartier, E. 2002. Dosage de certains métaux traces (Cd, Co, $\mathrm{Cu}, \mathrm{Fe}, \mathrm{Ni}, \mathrm{Pb}, \mathrm{Zn})$ dissous dans l'eau de mer par absorption atomique après extraction liquide-liquide. Editions Ifremer, Brest, France, 39 pp.

CIESM, 2002. Mediterranean mussel watch-designing a regional program for detecting radionuclides and trace contaminants. CIESM workshops series, $\mathbf{1 5}, 136 \mathrm{pp}$. 
Cossa, D. 1989. A review of the use of Mytilus sp. As a quantitative indicators of cadmium and mercury contamination in coastal waters. Oceanologica Acta, 12, 417-432.

Cossa, D., Bourget, E., Pouliot, D., Piuze, J., Chanut, J.P. 1980. Geographical and seasonnal variations in the relationship between trace metal content and body weight in Mytilus edulis. Marine Biology, 58, 7-14.

Cossa, D., Coquery, M., Nakhlé, K., Claisse, D. 2002. Dosage du mercure total et du monométhylmercure dans les organismes et les sédiments marins. Editions Ifremer, Brest, France, 28 pp.

Cossa, D., Averty, B., Bretaudeau, J., Senard, A.-S. 2003. Spéciation du mercure dissous dans les eaux marines. Méthodes d'analyse en milieu marin. Co-édition Ifremer et Ministère de l'Ecologie et du Développement Durable. 27 pp. ISBN 2-84433-125-4.

Cossa, D., Rondeau, J-G. 1985. Seasonal, geographical and size-induced variability in mercury content of Mytilus edulis in an estuarine environment: a reassessment of mercury pollution level in the estuary and gulf of St Laurent. Marine Biology, $\mathbf{8 8}$, 43-49.

Cubadda, F, Conti, M.E., Campanella, L. 2001. Size-dependant concentrations of trace metals in four Mediterranean gastropods. Chemosphere, 45, 561-569.

Davies, M.S., Cliff, E.J. 2000. Adsorption of metals in seawater to limpet Patella vulgata Pedal mucus. Bulletin of Environmental Contamination and Toxicology, 64, 228234. 
El-Rayis, O., Aboul-Dahab, K., Halim, Y., Riley, J. 1997. Metal accumulation in Mex Bay. $7^{\text {th }}$ International Conference "Environmental Protection is a must", Alexandria, Egypt, 53-59.

Fabris, J.G., Richardson, B.J., O'Sullivan, J.E., Brown, F.C. 1994. Estimation of cadmium, lead and mercury concentration in estuarine waters using the mussel Mytillus edulis planulatus L. Environmental Toxicology and Water Quality, 9, 183192.

Fisher, W., Bauchot, M.L., Schneider, M. 1987. Fiches FAO d'identification des espèces pour les besoins de la pêche. Méditerranée et mer Noire. Zone de pêche 37. Vol.1. Végétaux et Invertébrés. Publication FAO et commission de communautés européennes. Rome, FAO, 1, 760 pp.

Fowler, S.W. 1982. Biological transfer and transport processes. In : Pollutant transfer and transport at sea. p. 2-65. Kullenberg, G. (ed.) CRC Press, Boca Raton, USA.

Gagnon, C., Fisher, N. 1997. Bioavailability of Sediment-Bound Methyl and Inorganic Mercury to a Marine Bivalve. Environmental Science \& Technology, 31, 993-998.

Goldberg, E.D. 1975. The Mussel Watch : A first step in global marine pollution monitoring. Marine Pollution Bulletin, 6, 111 pp.

Herut, B., Kress, N., Hornung, H. 1999. Trace element levels in molluscs from clean and polluted coastal marine sites in the Mediterranean, Red and North seas. Helgoland Marine Resources, 53, 154-162.

Kayal, S.I. 1981. Cadmium levels in seawater, sediments, limpets and shrimps, along the coast of Lebanon. M.S. Thesis, American University of Beirut, 273 pp. 
Khalid, A. 1997. A comparative study for distribution of some heavy metals in aquatic organisms fished from Alexandria region. PhD Thesis, Alexandria University, Egypt.

Le-Loeuff, P., Zabi, G.S.F. 1994. Revue des connaissances sur la faune benthique des milieux margino-littoraux d'Afrique de l'Ouest. Revue d'Hydrobiologie Tropicale, 26, $127-137$.

McGeer, J.C., Brix, K.V., Skeaff, J.M., DeForest, D.K., Brigham, S.I., Adams, W.J., Green, A. 2003. Inverse relationship between bioconcentration factors and exposure concentration for metals: implications for hazard assessment of metals in the aquatic environment. Environmental Toxicology and Chemistry, 22, 1017-1037.

Mikac, N., Niessen, S., Ouddane, B., Wartel, M. 1999. Speciation of mecury in sediments of the Seine estuary (France). Applied Organometallic Chemistry, 13, 715-725.

Nakhlé, K. 2003. Le mercure, le cadmium et le plomb dans les eaux littorales libanaises : apports et suivi au moyen de bioindicateurs quantitatifs (éponges, bivalves et gastéropodes). Thèse de doctorat, Université Denis Diderot, Paris, France, 241 pp.

N.A.S. 1980. The International Mussel Watch. National Academy of Sciences US, Washington, $247 \mathrm{pp}$.

Phillips, D.J.H., Rainbow, P.S. 1993. Biomonitoring of trace aquatic contaminants. Environmental Managment Series, Alden Press Ltd, Oxford, 371 pp.

Qiu, J.W., Qian, P.-Y. Wang W.X. 2001. Contribution of dietary bacteria to metal accumulation in the slipper limpet. Aquatic Microbial Ecology, 25, 151-161. 
Quémerais, B., Cossa, D. 1995. Protocoles d'échantillonnage et d'analyse du mercure dans les eaux naturelles. Environnement canada - région du Québec, Centre SaintLaurent. Rapport scientifique et technique ST-31, 39p.

Ramelow, G. 1985. A study of heavy metals in limpets (Patella sp.) collected along a section of the south-eastern Turkish Mediterranean coast. Marine Environmental Research, 16, 243-253.

RNO. 1996. Surveillance du milieu marin. Travaux du réseau national d'observation de la qualité du milieu marin. Editions Ifremer, 32 pp.

Sanjuan, J., Cossa, D. 1993. Dosage automatique du mercure total dans les organismes marins par fluorescence atomique. Editions Ifremer, Nantes, France.

Shiber, J. 1977. Trace metals in two Ras Beirut Shore crabs. Cercetari Marine, 10, $185-$ 192.

Shiber, J., Shatila, T. 1978. Lead, cadmium, copper, nickel and iron in limpets, mussels and snails from the coast of Ras Beirut, Lebanon. Marine Environmental Research, 1, 125-134.

Szefer, P., Frelek, K., Szefer, K., Lee, C.B., Warzocha, J., Zdrojewska, I., Ciesielski, T. 2002. Distribution and relationships of trace metals in soft tissue, byssus and shell of Mytilus edulis trossulus from the southern Baltic. Environmental Pollution 120, 423-444.

Tuncer, S., Uysal, H. 1982. Etudes des métaux lourds chez les mollusques dans les différentes zones de la Baie d'Izmir (Turquie). CIESM, VIes Journées sur l'Etude des Pollutions, Cannes, France. 


\section{Figure captions}

Figure 1. Location of the sampling stations. SR: $2 \mathrm{~km}$ to the north of the industrial complex of Selaata; S: 500 m. south Selaata; B: Batroun (4 km the south of Selaata complex); K: Kfarkedde (7 km to the south of Selaata); H: Halate (3 km north of Nahr Ibrahim river); J: Jounieh Bay; Z: Zouk (coal power plant); N: Nahr el Kalb river estuary; A: Estuary of the Nahr Antelias river.

Figure 2. Relationships between metal concentrations in the soft tissue and the size of the mussel (B. variabilis).

Figure 3. Relationships between metal concentrations in the soft tissue and the size of the limpet (Patella sp.)

Figure 4. Average seasonal metal concentrations in the soft tissues of the mussel $(B$. variabilis) from various stations along the Lebanese coasts (figure 1 for station identification).

Figure 5. Average seasonal metal concentrations in the soft tissues of the limpet (Patella sp.) from various stations along the Lebanese coasts (figure 1 for station identification).

Figure 6. Comparison of metal concentrations in mussel (B. variabilis) and in near-shore surface waters (within $400 \mathrm{~m}$ from the shore line) from stations SR, S and H. Each point represents the mean \pm standard deviation for one station (data from tables 2 and 6). 
Table 1. Locations and characteristics of the sampling stations. See also the map on Figure 1.

\begin{tabular}{|c|c|c|}
\hline Station & Location & Main characteristic \\
\hline SR & North-Selaata $\left(34^{\circ} 16^{\prime} 22.8 \mathrm{~N} ; 35^{\circ} 39^{\prime} 35.0 \mathrm{E}\right)$ & $\begin{array}{l}2 \mathrm{~km} \text { north of the industrial Selaata } \\
\text { complex }\end{array}$ \\
\hline $\mathrm{S}$ & Selaata $\left(34^{\circ} 16^{\prime} 22.5 \mathrm{~N} ; 35^{\circ} 39^{\prime} 40.9 \mathrm{E}\right)$ & $\begin{array}{l}\text { Fertilizer and chemical plants complex } \\
\text { (phosphoric acid, phosphogypsum, sulfuric } \\
\text { and Hydrochloric acids) }\end{array}$ \\
\hline B & Batroun $\left(34^{\circ} 15^{\prime} 07.0 \mathrm{~N} ; 35^{\circ} 39^{\prime} 43.5 \mathrm{E}\right)$ & $\begin{array}{l}4 \mathrm{~km} \text { south of Selaata free from direct } \\
\text { effluents }\end{array}$ \\
\hline K & Kfarkeddé (335'21.6N; 35³8’13.8E) & $\begin{array}{l}7 \mathrm{~km} \text { south of Selaata free from urban and } \\
\text { industrial activities }\end{array}$ \\
\hline $\mathrm{H}$ & Halate $\left(34^{\circ} 15^{\prime} 07.0 \mathrm{~N} ; 35^{\circ} 39^{\prime} 43.5^{\mathrm{E}}\right)$ & Quite pristine zone \\
\hline $\mathrm{J}$ & Jounieh $\left(33^{\circ} 59^{\prime} 21.6 \mathrm{~N} ; 35^{\circ} 38^{\prime} 13.8 \mathrm{E}\right)$ & Large city with untreated urban sewage \\
\hline $\mathrm{Z}$ & 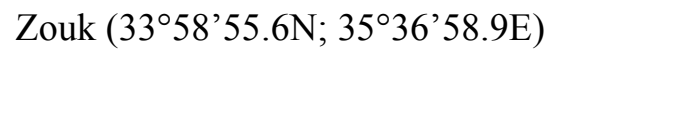 & $\begin{array}{l}\text { Harbor activities and a large coal power } \\
\text { plant }\end{array}$ \\
\hline $\mathrm{N}$ & Nahr el Kalb (335’’34.9N; 35³5’69.4E) & $\begin{array}{l}\text { Estuary of the el Kalb River receiving the } \\
\text { effluents of small industries }\end{array}$ \\
\hline A & 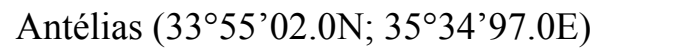 & Industrialized area north of Beirut \\
\hline
\end{tabular}


Table 2. Means ( \pm sd) for cadmium, lead and mercury concentrations in near-shore surface waters near the sampling sites (within $400 \mathrm{~m}$ off the shore line). Ranges of variation are in brackets. Samples (8) were taken in summer 2002 and winter 2003 (only 4 summer samples are available for $\mathrm{Hg}$ ). The large seasonal variations in metal concentration are mainly governed by the wind direction (Nakhlé, 2003).

\begin{tabular}{lccc}
\hline Station & $\mathrm{Cd}\left(\mathrm{ng} \mathrm{L}^{-1}\right)$ & $\mathrm{Pb}\left(\mathrm{ng} \mathrm{L}^{-1}\right)$ & $\mathrm{Hg}\left(\mathrm{ng} \mathrm{L}^{-1}\right)$ \\
\hline $\mathrm{SR}$ & $62 \pm 36(16-156)$ & $47 \pm 15(24-76)$ & $0.44 \pm 0.08(0.30-0.55)$ \\
$\mathrm{S}$ & $32 \pm 22(7-220)$ & $221 \pm 187(21-876)$ & $0.31 \pm 0.03(0.27-0.36)$ \\
$\mathrm{H}$ & $6.5 \pm 0.5(6-8)$ & $29 \pm 12(16-62)$ & $0.44 \pm 0.07(0.34-0.57)$ \\
\hline
\end{tabular}


Table 3. Metal concentrations in mussel soft tissue (B. variabilis). ANOVA with station, year and condition index (CI) as discriminatory factors. CI is a proxy for physiological state, tautological for season.

\begin{tabular}{lccccc}
\hline Factor & $\begin{array}{c}\text { Degree of } \\
\text { freedom }\end{array}$ & $\begin{array}{c}\text { Sum of } \\
\text { squares }\end{array}$ & $\begin{array}{c}\text { Square } \\
\text { average }\end{array}$ & $\mathrm{F}$ & $\begin{array}{c}\text { Probability of } \\
\mathrm{F}\end{array}$ \\
\hline Cadmium & & & & & \\
Station & 4 & 15.379 & 3.845 & 194.866 & $10^{-8}$ \\
Year & 2 & 0.156 & 0.078 & 3.998 & 0.019 \\
CI & 1 & 2.626 & 2.626 & 133.081 & $10^{-8}$ \\
Residue & 331 & 6.531 & 0.020 & - & - \\
Lead & & & & & \\
Station & 4 & 5.821 & 1.455 & 58.934 & $<10^{-8}$ \\
Year & 2 & 1.039 & 0.519 & 21.034 & $<10^{-8}$ \\
CI & 1 & 2.804 & 2.804 & 133.547 & $<10^{-8}$ \\
Residue & 331 & 8.173 & 0.025 & - & - \\
Mercury & & & & & \\
& & & & & $<10^{-8}$ \\
Station & 4 & 12.456 & 3.114 & 172.218 & $\mathrm{NS}$ \\
Year & 2 & 0.045 & 0.022 & 1.234 & $210^{-8}$ \\
CI & 1 & 2.489 & 2.489 & 137.676 & - \\
Station*Year & 8 & 0.559 & 0.070 & 3.864 & - \\
Residue & 323 & 5.840 & 0.0181 & & - \\
\hline
\end{tabular}


Table 4. Metal concentrations in limpet soft tissue (Patella sp.). ANOVA with station, year and condition index (CI) as discriminatory factors. CI is a proxy for physiological state, tautological for season.

\begin{tabular}{lccccc}
\hline Factor & $\begin{array}{c}\text { Degree of } \\
\text { freedom }\end{array}$ & $\begin{array}{c}\text { Sum of } \\
\text { squares }\end{array}$ & $\begin{array}{c}\text { Square } \\
\text { average }\end{array}$ & F & $\begin{array}{c}\text { Probability of } \\
\text { F }\end{array}$ \\
\hline Cadmium & & & & & \\
Station & 8 & 96.226 & 12.028 & 237.348 & $<10^{-8}$ \\
Year & 2 & 1.789 & 0.894 & 17.648 & $3.610^{-7}$ \\
CI & 1 & 2.826 & 2.826 & 55.770 & $<10^{-8}$ \\
Station*year & 16 & 2.321 & 0.145 & 2.863 & $1.610^{-4}$ \\
Residue & 606 & 30.711 & 0.051 & - & - \\
Lead & & & & & \\
Station & 8 & 21.884 & 2.736 & 87.481 & $<10^{-8}$ \\
Year & 2 & 1.611 & 0.805 & 25.752 & $10^{-8}$ \\
CI & 1 & 2.649 & 2.649 & 84.726 & $<10^{-8}$ \\
Station*year & 16 & 2.0226 & 0.127 & 4.049 & $2.210^{-7}$ \\
Residue & 605 & 18.919 & 0.031 & - & - \\
Mercury & & & & & \\
Station & & & & & $<10^{-8}$ \\
Year & 8 & 19.193 & 2.399 & 109.673 & $<10^{-8}$ \\
CI & 2 & 0.512 & 0.256 & 11.711 & - \\
Station*year & 1 & 1.071 & 1.071 & 48.945 & $-10^{-8}$ \\
Residue & 6 & 2.821 & 0.176 & 8.059 & - \\
\hline & & 13.213 & 0.022 & & - \\
\hline
\end{tabular}


Table 5. Relationships between metals concentrations in soft tissue of mussel (B. variabilis) (ng. $\mathrm{mg}^{-1}, \mathrm{dw}$ ) and the condition index (CI, ratio without unit) at different stations along the Lebanese coasts (figure 1 for station identification). Each point corresponds to each seasonal samples (mean of 10 individuals) collected during the two-year period. (*) significant with $\mathrm{P} \leq$ 0.05 .

\begin{tabular}{llccc}
\hline Metal & Station & $\mathrm{R}^{2}$ & Slope & Origin \\
\hline Cadmium & $\mathrm{SR}$ & $0.64^{*}$ & -58.00 & +6.57 \\
& $\mathrm{~S}$ & 0.43 & - & - \\
& $\mathrm{B}$ & $0.67^{*}$ & -42.01 & +3.70 \\
& $\mathrm{~K}$ & 0.45 & - & - \\
\hline \multirow{2}{*}{ Lead } & $\mathrm{H}$ & 0.37 & - & - \\
& $\mathrm{SR}$ & $0.88^{*}$ & -49.51 & +3.96 \\
& $\mathrm{~S}$ & 0.32 & - & - \\
& $\mathrm{B}$ & $0.87^{*}$ & -29.01 & - \\
& $\mathrm{K}$ & 0.02 & - & - \\
\hline \multirow{2}{*}{ Mercury } & $\mathrm{H}$ & 0.39 & - & - \\
& $\mathrm{SR}$ & 0.03 & - & +0.48 \\
& $\mathrm{~S}$ & 0.39 & - & +0.35 \\
& $\mathrm{~B}$ & $0.75^{*}$ & -4.80 & +0.27 \\
\hline
\end{tabular}


Table 6. Adjusted mean concentrations $( \pm \mathrm{sd})$ for $\mathrm{Cd}, \mathrm{Pb}$ and $\mathrm{Hg}\left(\mathrm{ng} \cdot \mathrm{mg}^{-1}, \mathrm{dw}\right)$ in the soft tissue with respect to the condition index of the mussel (B. variabilis). The normalization was performed for a fixed CI arbitrarily set at 0.05 .

\begin{tabular}{lccccc}
\hline Station & SR & S & B & K & H \\
\hline Cadmium & $3.67 \pm 0.40$ & $3.00 \pm 0.13$ & $1.60 \pm 0.29$ & $1.36 \pm 0.28$ & $1.19 \pm 0.20$ \\
Lead & $1.51 \pm 0.17$ & $2.45 \pm 0.55$ & $1.29 \pm 0.11$ & $1.59 \pm 0.56$ & $0.93 \pm 0.31$ \\
Mercury & $0.55 \pm 0.07$ & $0.24 \pm 0.02$ & $0.24 \pm 0.05$ & $0.21 \pm 0.03$ & $0.18 \pm 0.02$ \\
\hline
\end{tabular}

Table 7. Comparison of mean metal concentrations (ng $\mathrm{mg}^{-1}, \mathrm{dw}$ ) within Mytilidae from Lebanon (B. variabilis), France and USA (Mytilus sp.). French and American means are issued from RNO report (1996), they refer to more than 500 data sets.

\begin{tabular}{lccc}
\hline Country & Cadmium & Lead & Mercury \\
\hline France & 1 & 2.7 & 0.16 \\
USA & 1.6 & 1.9 & 0.12 \\
Lebanon & $2.17 \pm 1.45$ & $1.64 \pm 0.97$ & $0.25 \pm 0.18$ \\
\hline
\end{tabular}




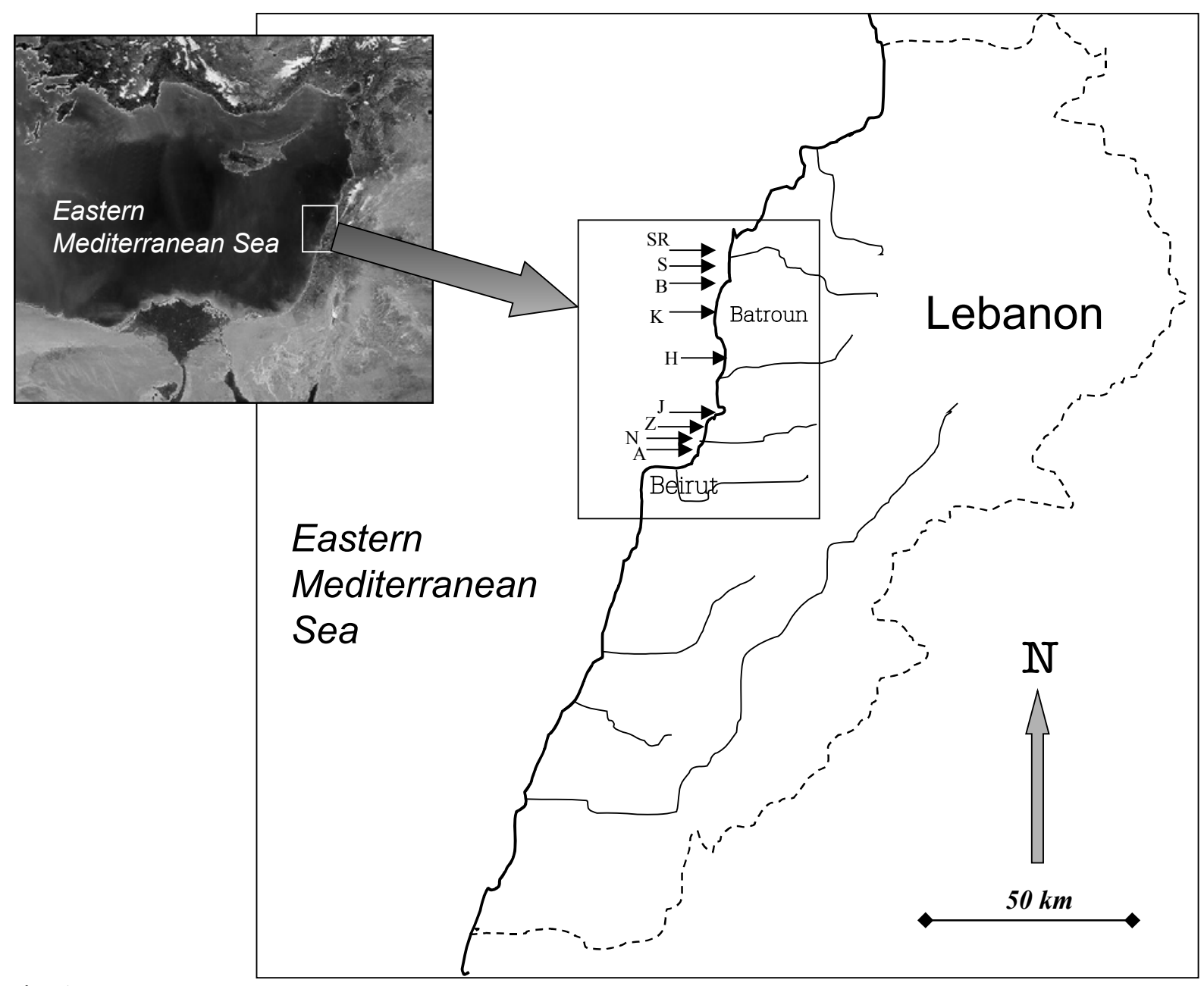

Fig. 1 


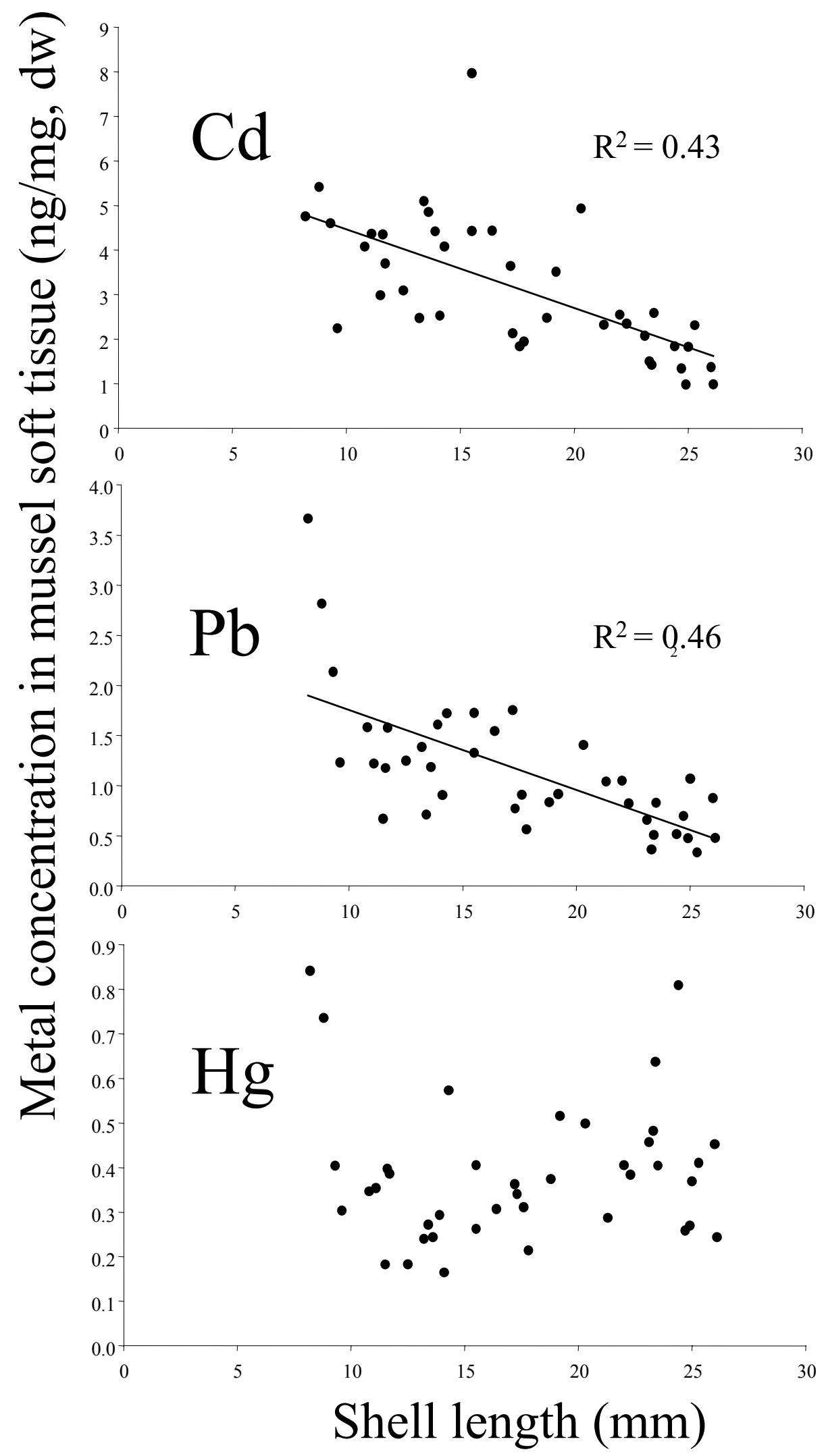

Fig. 2 


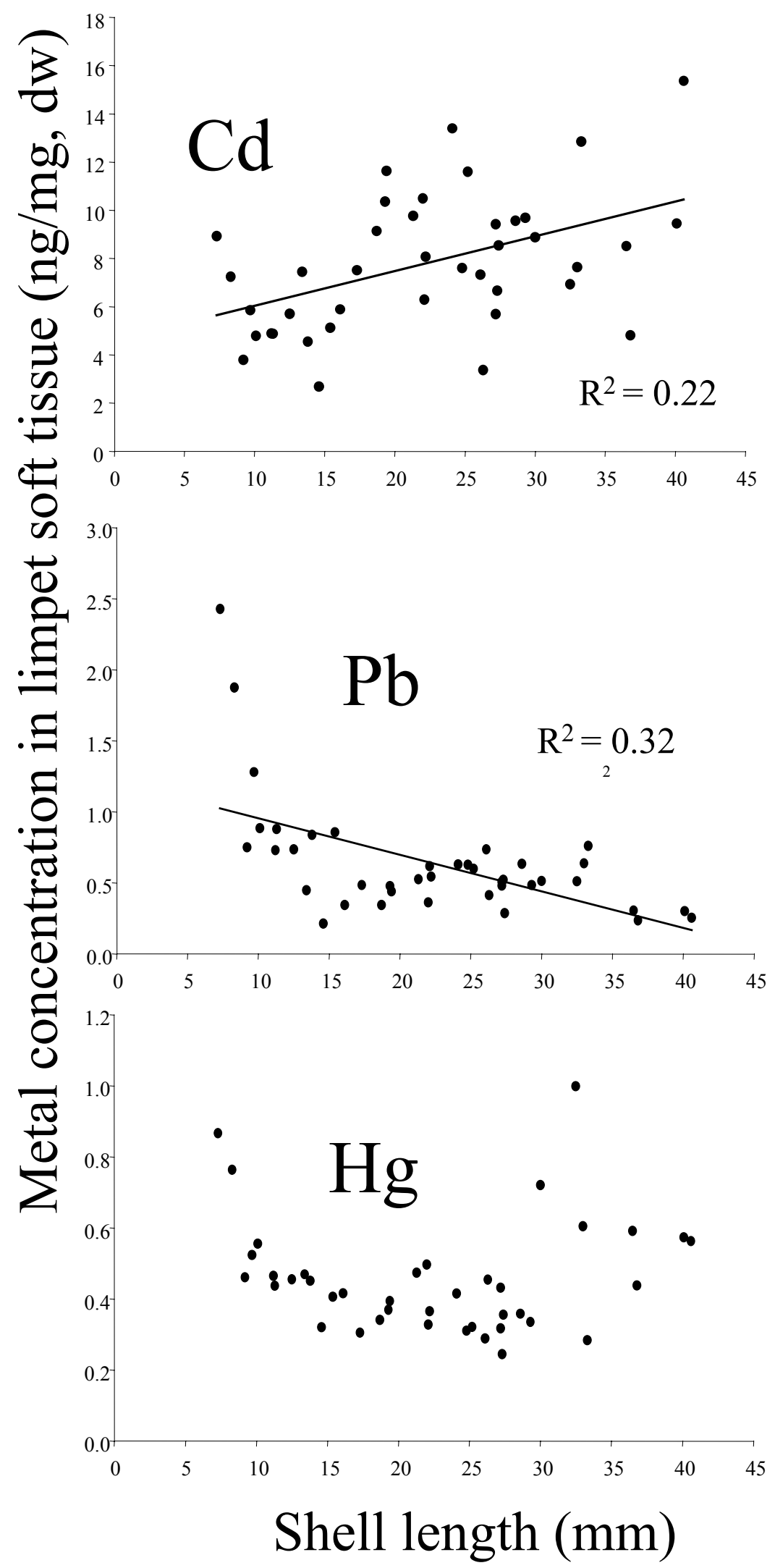

Fig. 3 


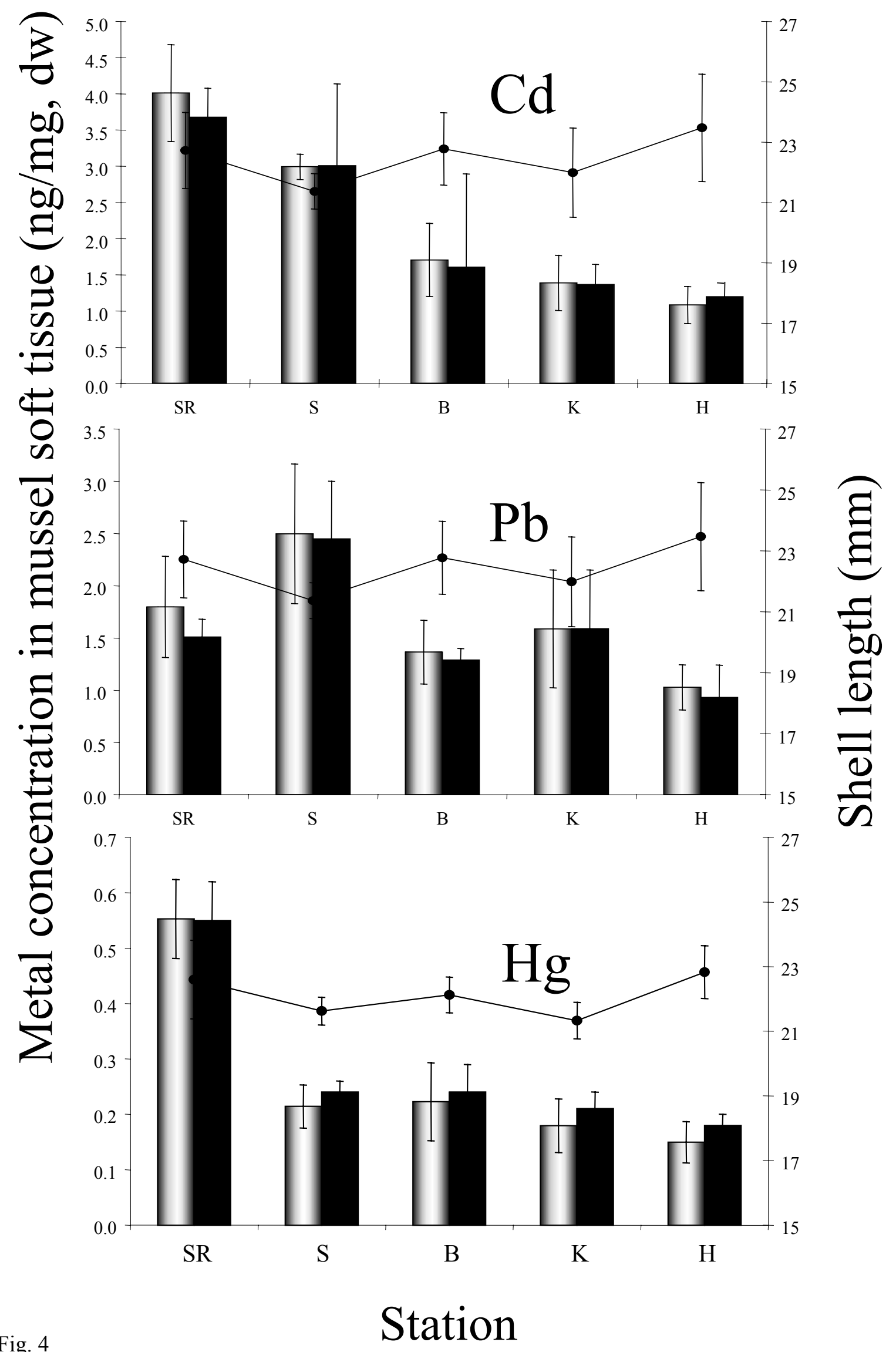

Fig. 4 


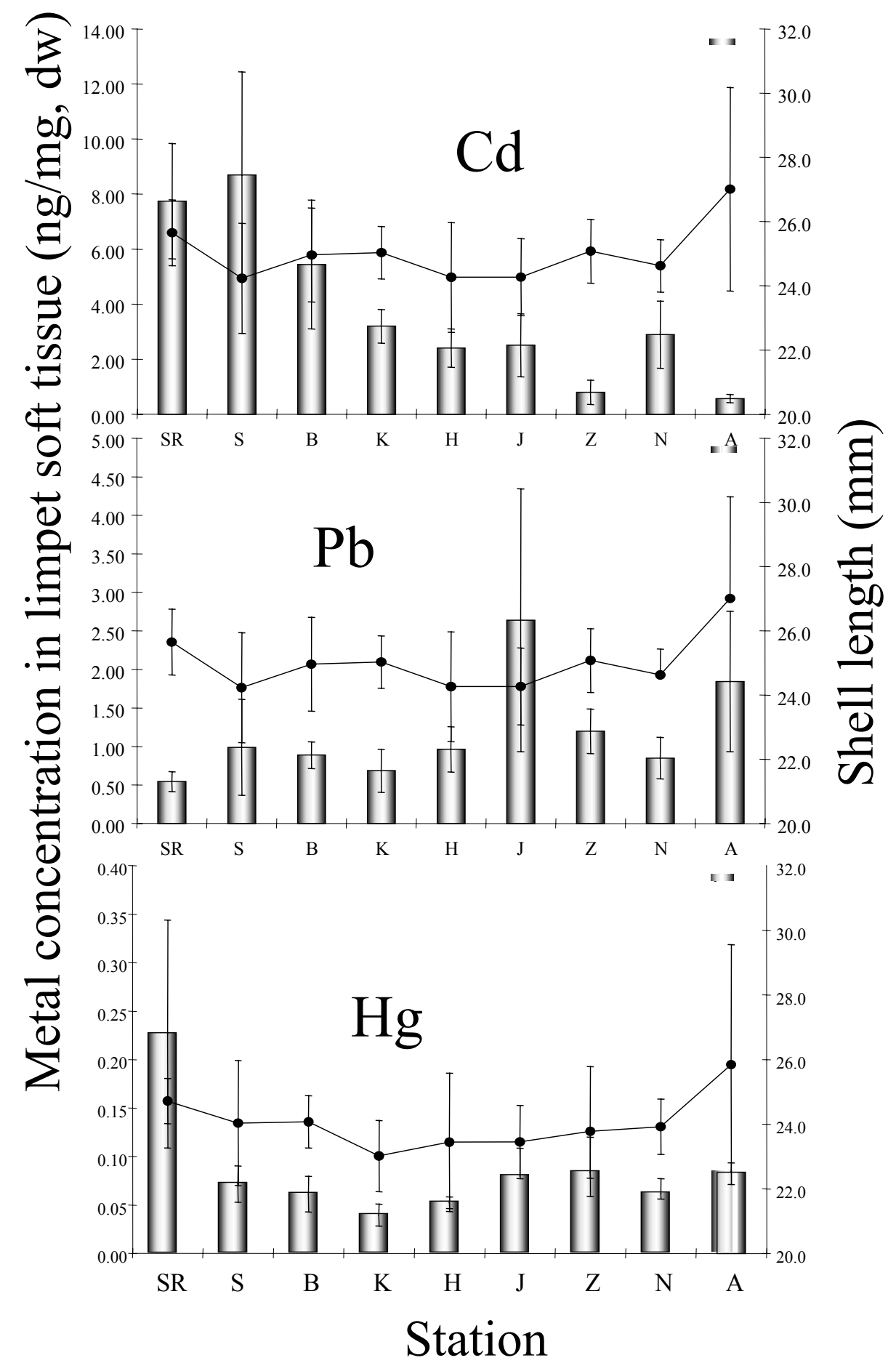

Fig. 5 

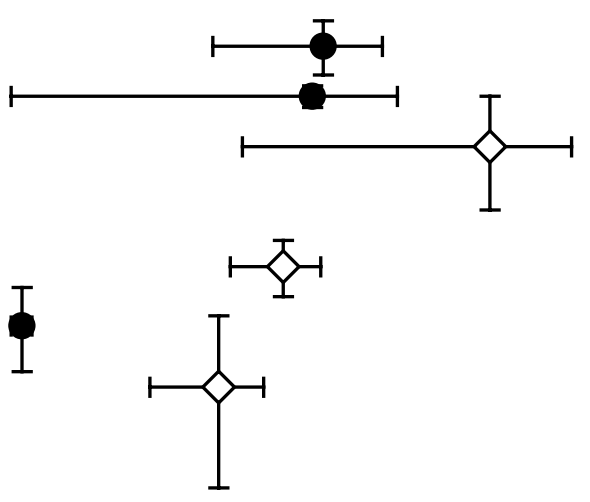

$$
\begin{aligned}
& \odot \mathrm{Cd} \\
& \mathrm{OHg} \\
& \diamond \mathrm{Pb}
\end{aligned}
$$

Metal in water (ng/L)

Fig. 6 